\title{
Ultrasound Imaging to Estimate Carcass Quality of Pasundan Cattle based on Body Condition Score
}

\author{
Khairunnisa $\mathrm{S}^{1}$, Novelina $\mathrm{S}^{1}$, Hilmia $\mathrm{N}^{2}$, Hadi $\mathrm{DN}^{3}$, Rahmat $\mathrm{D}^{2}$, Ulum $\mathrm{MF}^{1,4, *}$ \\ ${ }^{1}$ Faculty of Veterinary Medicine, IPB University, Jl. Agatis, Dramaga, Bogor 16680 - Indonesia \\ ${ }^{2}$ Faculty of Animal Husbandry, Padjadjaran University, Jl. Raya Bandung-Sumedang KM. 21, Jatinangor, Sumedang 45363 - Indonesia \\ ${ }^{3}$ Center for Artificial Insemination and Artificial Insemination for Beef Cattle Development (UPTD BPPIB), Ciamis 46271 - Indonesia \\ ${ }^{4}$ Veterinary Teaching Hospital, Faculty of Veterinary Medicine, IPB University, Jl. Agatis, Dramaga, Bogor 16680 - Indonesia \\ *Corresponding Email: ulum@ipb.ac.id
}

(received 11-11-2020; revised 16-01-2021; accepted 18-01-2021)

\begin{abstract}
ABSTRAK
Khairunnisa S, Novelina S, Hilmia N, Hadi DN, Rahmat D, Ulum MF. 2021. Pencitraan ultrasonografi untuk pendugaan kualitas karkas pada Sapi Pasundan berdasar nilai kondisi tubuh. JITV 26(1): 1-9. DOI:http//dx.doi.org/10.14334/jitv.v26i1.2584.

Penelitian ini bertujuan untuk mengestimasi kualitas karkas pada Sapi Pasundan menggunakan citra ultrasonografi (USG) berdasarkan nilai kondisi tubuh (NKT) yang berbeda. Sapi Pasundan betina total sebanyak 31 ekor sapi berumur 4-7 tahun dari Unit Pelaksana Teknis Daerah Balai Perbibitan dan Pengembangan Inseminasi Buatan Ternak Sapi Potong Ciamis Jawa Barat Indonesia dengan NKT 1,0-4,0 digunakan dalam penelitian ini. Skor marbling, intramuscular fat (IMF), tebal lemak punggung (LP), dan tebal otot dari m. longissimus dorsi (LD), m. psoas major (PM), m. psoas minor (PMN), serta m. gluteus medius (GM) diambil menggunakan pencitraan USG pada 3 lokasi berbeda yaitu pada tulang rusuk 12-13 (thorax), lumbal 4-5 (lumbal) dan diantara tuber coxae dan tuber ischii (gluteal) dengan frekuensi $5 \mathrm{MHz}$ dari transduser convex. Hasil analisa menunjukkan bahwa peningkatan NKT berbanding lurus dengan peningkatan tebal LP, ketebalan otot, skor marbling dan skor IMF dari m. LD, m. PM, m. PMN, dan m. GM. Sapi Pasundan memiliki rentang skor marbling 1-5 dan rentang persentase IMF 2,62\%$4,82 \%$. Nilai kondisi tubuh sapi pasundan memengaruhi kualitas karkas pada parameter seperti ketebalan otot, skor marbling dan persentase intramuscular fat dari citra ultrasonografi m. LD, m. PM, m. GM dan m. PMN.
\end{abstract}

Kata Kunci: NKT, Sapi pasundan, Karkas, Ultrasonografi

ABSTRACT

Khairunnisa S, Novelina S, Hilmia N, Hadi DN, Rahmat D, Ulum MF. 2021. Ultrasound imaging to estimate carcass quality of Pasundan cattle based on body condition score. JITV 26(1): 1-9. DOI:http//dx.doi.org/10.14334/jitv.v26i1.2584.

This research aimed to estimate carcass quality of Pasundan cattle using ultrasound imaging based on Body Condition Score (BCS). Total 31 head of female cattle with age ranging from 4 to 7 years from Regional Technical Implementation Unit of the Center for Artificial Insemination and Artificial Insemination for Beef Cattle Development at Ciamis West Java, Indonesia with BCS ranging from 1.0-4.0. The marbling score, intramuscular fat (IMF), backfat thickness (LP), and thickness musculus of m. longissimus dorsi (LD), m. psoas major (PM), m. psoas minor (PMN), m. gluteus medius (GM) and m. biceps femoris (BF) were scanned using ultrasound on 3 different locations, i.e. on $12^{\text {th }}-13^{\text {th }}$ ribs (thorax), lumbar $4^{\text {th }}-5^{\text {th }}$ (lumbar), and between tuber coxae and tuber ischii (gluteal) with $5 \mathrm{MHz}$ frequency of convex transducer. The results showed that BCS increased when LP, marbling score and IMF from $\mathrm{m}$. LD, m. PM, m. PMN, and m. GM was rising. Pasundan cattle showed marbling scores ranging from score 1 to 5 and percentage IMF ranging from 2.62\% to 4.82\%. Body Condition Score affected carcass quality of Pasundan cattle on parameters such as musculus thickness, marbling score, and intramuscular fat (IMF) from ultrasound imaging of $\mathrm{m}$. LD, m. PM. m. PMN, m. GM, and m. BF.

Key Words: BCS, Carcass, Pasundan cattle, Ultrasound

\section{INTRODUCTION}

Pasundan cattle are the result of adaptation and crossing of more than ten generations of Balinese cows with Ongole crossbreeds, Sumba Ongole, and Madura cows (Kementerian Pertanian 2014). Pasundan cattle are known as the genetic resources of local livestock belonging to West Java based on the Decree of the Minister of Agriculture No: 1051/Kpts/SR.120/10/2014 at 13 October 2014 concerning the determination of the Pasundan cattle breed. The advantages of Pasundan cattle are efficiency in maintenance, relatively simple housing, disease/parasite resistance, thirst resistance, resistance to weather changes, short reproductive cycles, high feed efficiency, and a high percentage of carcasses (Indrijani et al. 2012). Pasundan cattle can contribute to meeting the demand for beef, especially in West Java by 20 percent of the 515 thousand head per year (Dinas Peternakan Jawa Barat 2016).

Factors taken into account in assessing meat and carcass quality in cattle according to USDA standards include carcass weight, carcass length, backfat 
thickness, longissimus dorsi muscle thickness, pelvic fat percentage, marbling score, and fat color (Nold et al. 1992). Ultrasound imaging has been used since 1960 to measure muscle fat thickness in beef cattle which is a parameter in the Quality Beef Contest at the International Livestock Exposition (Stouffer 2004). Ultrasonography (USG) is a technique that is widely used for in vivo prediction of carcass or body composition in cattle, pigs, goats, and also sheep (Stouffer 2004). Ultrasound imaging can be used to determine meat and fat characteristics in live animals, specifically intramuscular fat percentage and marbling score (Gupta et al. 2013). The characteristics of the carcass and the quantity and quality of meat can be evaluated periodically, routinely, and more accurately by using ultrasound (Bugiwati et al. 2000). Furthermore, ultrasound imaging is non-distracting to livestock, is relatively inexpensive, and is a useful method for evaluating the condition of subcutaneous muscle and adipose tissue (Stouffer 2004).

The body condition score (BCS) is a method for interpreting body fat reserves using senses of sight and touch, subjectively (Edmonson et al. 1989). These reserves of body fat were used to cover the lack of energy from feed during delivery and milk production. The BCS assessments have been accepted as a simple and inexpensive method that is used for estimating body fat used in both commercial livestock and research activities (Otto et al. 1991). Two scale methods have been used in determining BCS, namely, a scale of 1-9 (America) and a scale of 1-5 (UK and Commonwealth country), and in Indonesia, BCS assessment generally use a scale of 1-5 (M'hamdi et al. 2012). Assessment of the ideal BCS for livestock is highly dependent on the purpose of raising the livestock. For cattle that are raised as livestock producing or fattening meat, the greater the value of their BCS will be better and very profitable the livestock business (Syaifudin 2013). This study aims to estimate the carcass quality of Pasundan cattle using ultrasound images based on different BCS. This research is expected to provide information regarding the estimation of carcass quality in Pasundan cattle using ultrasound images based on BCS as one of the considerations and evaluations in the breeding program of livestock breeds.

\section{MATERIALS AND METHODS}

The research was conducted at the Regional Technical Implementation Unit of the Center for Artificial Insemination and Artificial Insemination for Beef Cattle Development (UPTD BPPIB) at Ciamis, West Java. The 31 female Pasundan cows with natural conditions from various ages ranging from 4-7 years used in this study were then grouped based on BCS through direct visual observation with a scale of 1.0-5.0 (Roche et al. 2009). The variables observed were body condition score (BCS), backfat thickness (LP), $\mathrm{m}$. longissimus dorsi thickness (LD), m. psoas major thickness (PM), m. psoas minor thickness (PMN), m. gluteus medius thickness (GM), m. biceps femoris thickness (BF), marbling score (MS), and percentage of intramuscular fat (IMF). These variable data were obtained by using an ultrasound image console (Sonodop S-3X, PT Karindo Alkesteron) with a convex transducer having a frequency of $5 \mathrm{MHz}$ on a scanning area depth of $11.4 \mathrm{~cm}$.

Ultrasound is performed to scan LP, m. LD, m. PM on the chest following the method of Jakaria et al. (2017) on $12^{\text {th }}-13^{\text {th }}$ ribs, and the lumbar part above the flank at $4^{\text {th }}-5^{\text {th }}$ lumbar bone, which is more backward than Tait (2016) has done. Thickness measurement $\mathrm{m}$. $\mathrm{BF}, \mathrm{m}$. GM, m. LD, and $\mathrm{m}$. PM in the gluteus follows the method used by Silva et al. (2012) between the ischium and ilium bones (Figure 1). Ultrasound scans were taken transversally and longitudinally against the axis of the body for each part imaged (Figure 1). Ultrasound scan is performed transcutaneously on the skin with previously shaved hair using a hair razor and cleaned with soapy water. The ultrasonic gel is used as a contact agent to facilitate the interface between the probe and the skin to produce a good image. After the scan was complete, an antibiotic and anti flies spray (Limoxin 25 spray, PT. TMC Indonesia) was applied to the image location to prevent flies from settling on.

The results of ultrasound imaging were stored in BMP format and then presented descriptively and the data were analyzed quantitatively by using Microsoft Excel and ImageJ applications (NIH, USA) software. Quantitative data assessment was carried out by measuring skin thickness, subcutaneous thickness, muscle thickness, area, and intensity of gray color $\mathrm{m}$. LD, m. PM, m. GM, m. BF and m. PMN, and then assessing the marbling score and the IMF percentage based on AUS-MEAT Standard (AUS-MEAT 2020).

\section{RESULTS AND DISCUSSION}

Figure 2 shows the ultrasound image of the muscle in Pasundan cattle. Three different image scanning locations (thorax, lumbar and gluteal) wherein one location was imaged in two transducer positions namely transverse and longitudinal. The carcass composition in the thorax (Figure 2A and 2B) consists of skin, back fat (LP), and $\mathrm{m}$. LD. The lumbar part (Figure 2C and 2D) of carcass composition consists of skin, subcutaneous fat, m. LD, m. PM, and m. PMN. The composition of the rump / gluteal carcass (Figure 2E and 2F) consists of skin, subcutaneous fat, m. BF, m. GM, m. LD, and m. PM. Muscles imaged on the sonogram display as gray color or areas of less echogenicity. 

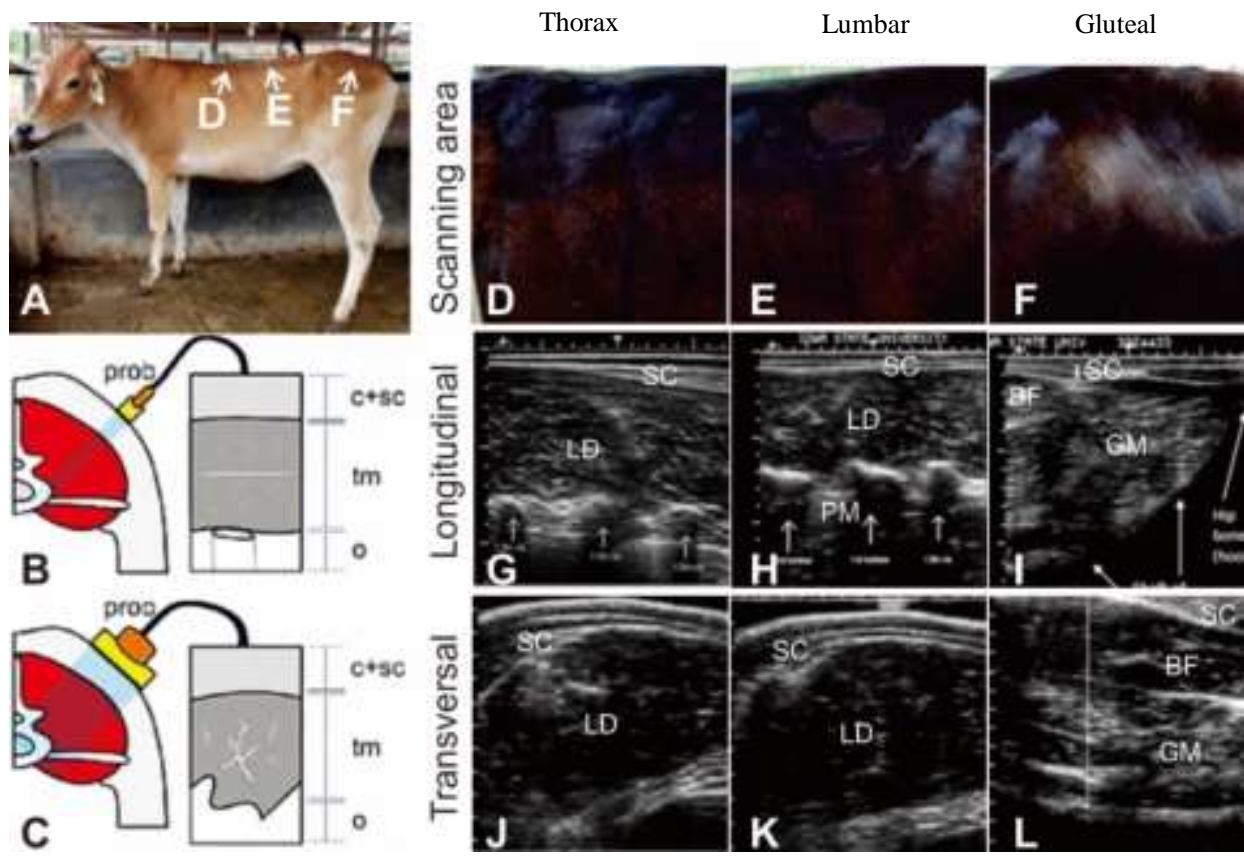

Figure 1. (A) Location of ultrasound imaging of Pasundan cattle; transducer display at (B) longitudinal and $(\mathrm{C})$ transversal view, prob= transducer, $\mathrm{c}=$ cutan, $\mathrm{s}=$ subcutan, $\mathrm{tm}=$ muscle thickness, $\mathrm{o}=$ bone (adapted from Ulum et al. 2014). Scanning area (D) thorax, (E) lumbar, (F) gluteal; image of the ultrasound imaging at the image scanning view (G) thorax longitudinal, (H) lumbar longitudinal, (I) gluteal longitudinal, $(\mathrm{J})$ thorax transversal, $(\mathrm{K})$ lumbar transversal, (L) gluteal transversal (adapted from Tait 2016); LD= $m$. longissimus dorsi, $\mathrm{PM}=m$. psoas major, $\mathrm{BF}=m$. biceps femoris, $\mathrm{GM}=m$. gluteus medius

Sonogram of skin, LP, muscle fat, muscle collagen, and bone shows white color or shows higher echogenicity than the surrounding tissue. The image pattern produced from the 3 locations is the same, namely, the live carcass composition is directly proportional to BCS.

The thickness of LP, m. LD, m GM, m. PM, and m. PMN in Pasundan cattle with different BCS can be seen in Figure 3. The thickness of LP and $\mathrm{m}$. LD in Figure $3 \mathrm{~A}-\mathrm{F}$ shows that the thickness is in line with the increase in BCS. Imaging positions in the gluteal area (Figure $3 \mathrm{E}$ and $3 \mathrm{~F}$ ) showed that $\mathrm{m}$. LD thickness increased dynamically with increasing BCS, but decreased at BCS 3.5-4.0. The location of the image that shows the thickest $\mathrm{m}$. LD with the smallest standard deviation is at the position of the thorax imaging (Figure 3A and 3B). The thickness of $\mathrm{m}$. GM and $\mathrm{m}$. BF (Figure $3 \mathrm{E}$ and $3 \mathrm{~F}$ ) showed the same results as the thickness of $\mathrm{m}$. LD where muscle thickness was directly proportional to BCS. The thickness of $\mathrm{m}$. PM at the lumbar imaging position (Figure 3C and 3D) showed a different graph pattern with the gluteal imaging positions (Figure 3E and 3F). The lumbar imaging position (Figure 3C and 3D) shows that the greater the BCS, the greater the $\mathrm{m}$. PM thickness. The gluteal imaging positions (Figure $3 \mathrm{E}$ and $3 \mathrm{~F}$ ) showed $\mathrm{m}$. PM thickness is only seen in cows with BCS 2.0-4.0 where each increase in BCS coincided with increasing m. PM thickness. PMN muscles were only imaged in the lumbar imaging position (Figure 3C and 3D) in cows with BCS 2.0-3.5 where each increase in BCS showed a decrease in $\mathrm{m}$. PMN thickness.

The marbling score of Pasundan cattle with different BCS can be seen in Figure 4. Figure 4A-D shows the marbling score at $\mathrm{m}$. LD increases from 1 to 5 along with the increase in BCS. The marbling score at $\mathrm{m}$. LD from the gluteal imaging position (Figure $4 \mathrm{E}$ and $4 \mathrm{~F}$ ) showed a dynamic increase with increasing BCS but then a decrease occurs in BCS 3.5-4.0. The highest marbling score of $\mathrm{m}$. LD was 5 at BCS 3.5-4.0 (Figure $4 \mathrm{C}$ and $4 \mathrm{~F}$ ). The marbling score for $\mathrm{m}$. PM can be seen in Figure 4C-F. The PM muscle in Figure $4 \mathrm{C}$ shows an increase from the 1 to 3 marbling score, then a decrease in BCS 2.5-3.0 to score 2 until it increases again and remains at score 3 at BCS 3.0-4.0. Whereas in Figure $4 \mathrm{E}-\mathrm{F}$ the $\mathrm{m}$. PM marbling score is only seen in cows with a BCS of 2.0-4.0. Each increase in BCS was accompanied by an increase in the $\mathrm{m}$. PM marbling score (Figure 4D-F). The marbling score for m. PMN was only seen at BCS 2.0-3.5, where each increase in BCS also increased the marbling score (Figure $4 \mathrm{C}$ and 4D). The 2 marbling score is the highest marbling score of $\mathrm{m}$. PMN at BCS 3.0-3.5 (Figure 4C). The m. GM and $\mathrm{m}$. BF which were located in the gluteal section showed that each increase in BCS was also followed by an increasing marbling score with the highest score of 4 at BCS 3.5-4.0 (Figure 4E and 4F).

The IMF value based on the AUS-MEAT carcass quality standard in Pasundan cattle can be seen in Figure 5. The results obtained are not much different 
from Figure 4. The IMF values on m. LD, m. GM, m $\mathrm{BF}, \mathrm{m}$. PM, and $\mathrm{m}$. PMN has increased along with the increase in BCS. Figure 5A-F shows the percentage of IMF in $\mathrm{m}$. LD. Cows with a BCS of 1.0-1.5 have the smallest IMF percentage range at $\mathrm{m}$. LD of $2.62 \%$ $2.80 \%$. The percentage of IMF in $\mathrm{m}$. LD with BCS 2.03.0 and $3.0-3.5$ are $2.77 \%-3.32 \%$ and $3.36 \%-3.88 \%$, respectively. The highest percentage of IMF in $\mathrm{m}$. LD was $3.39 \%-4.09 \%$ with BCS 3.5-4.0. The greatest percentage of m. PM was 4.00\% in BCS 3.5-4.0 (Figure 5D). The $\mathrm{m}$. GM and $\mathrm{m}$. BF showed the greatest percentage of IMF in each muscle, respectively $3.76 \%$ and $3.84 \%$ (Fig. 5E and 5F). The percentage of IMF $\mathrm{m}$. $\mathrm{PMN}$ is only seen in BCS 2.0-3.5, which shows the smallest percentage range of IMF from other muscles in the same image is $0.60 \%-1.73 \%$ (Figure 5C and 5D).

Ultrasound imaging is an objective method of measuring the carcass composition of live cattle that is effective, fast, and accurate (Lambe et al. 2010). Muscle imaged on the sonogram looks hypoechoic whereas LP, muscle fat, muscle collagen, and bone appear more hyperechoic. Soft tissue such as muscle will weaken some of the ultrasound waves transmitted in this way, so that it will show a gray or hypoechoic

Body Condition Score (BCS)

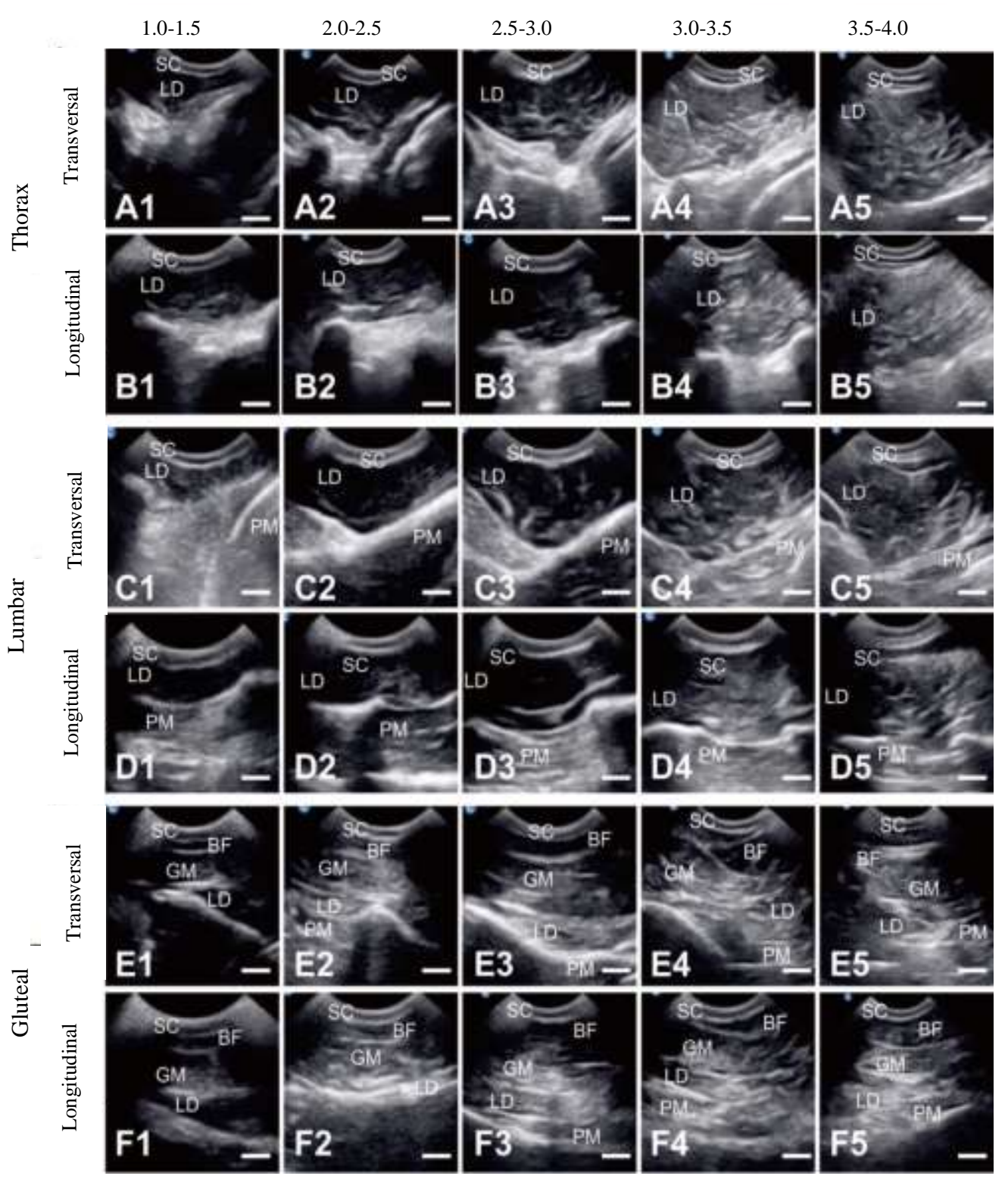

Figure 2. Sonogram of live carcass composition in Pasundan cattle with different BCS in scanning view of (A) Thorax transversal, (B) Thorax longitudinal, (C) Lumbar transversal, (D) Lumbar longitudinal, (E) Gluteal transversal, and (F) Gluteal longitudinal. Scale bar = $2 \mathrm{~cm}$ 

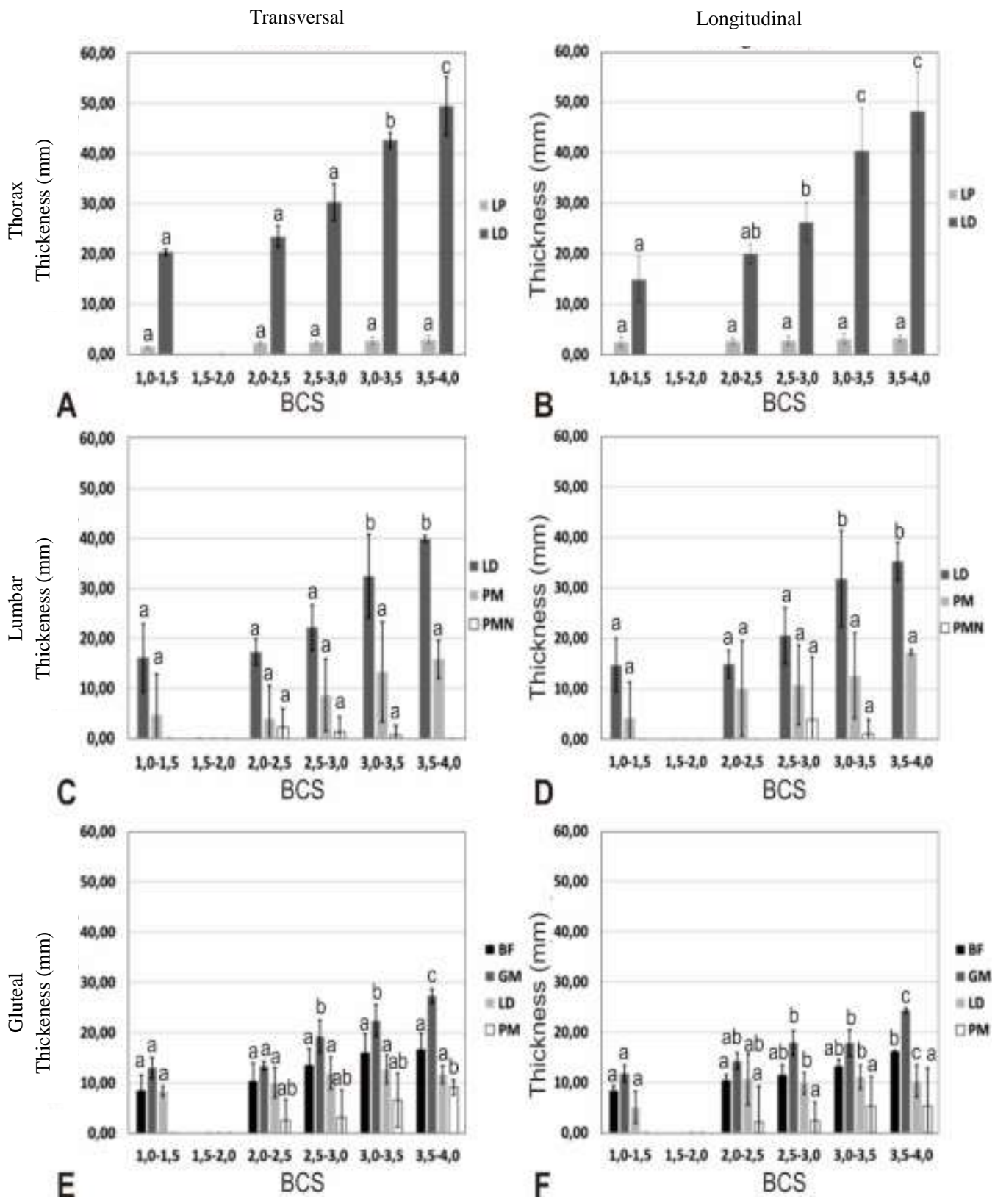

Figure 3. The thickness of back fat (LP), m. longissimus dorsi (LD), m. gluteus medius (GM), m. biceps femoris (BF), m. psoas major (PM), and $\mathrm{m}$. psoas minor (PMN) in Pasundan cattle with different of BCS. A) Thorax transversal, B ) Thorax longitudinal, C) Lumbar transversal, D) Lumbar longitudinal, E) Gluteal Transversal, and F) Gluteal longitudinal. Different superscript letters in the same muscle showed significant differences $(\mathrm{p}<0.05)$ between BCS in Pasundan cattle

color on the sonogram (Cruz-Arámbulo \& Wrigley 2003). Muscle, fat, and bone collagen will show a highly-reflective interface so that it will appear white or hyperechoic on the sonogram (Noviana et al. 2018). The composition of the carcass of Pasundan cattle that is imaged shows various results along with the varied BCS. BCS 3.5-4.0 (fat) presented a sonogram with the largest live carcass composition compared to low BCS (thin) (Figure 2). This is following the opinion of Juandhi et al. (2019) stated that carcass weight and composition will increase with increasing BCS of livestock.
Research has been conducted by Bergen et al. (2005) has shown that m. LD and LP thickness in cattle can be estimated using ultrasound at $12^{\text {th }}-13^{\text {th }}$ rib imaging sites. According to Tait (2016), ultrasound imaging of tissue at the $12^{\text {th }}-13^{\text {th }}$ ribs with a transverse position can measure the thickness of $\mathrm{m}$. LD and LP. This is following the results obtained in this study, the thickness of $\mathrm{m}$ LD and LP can be imaged in the thorax imaging location on $12^{\text {th }}-13^{\text {th }}$ ribs (Fig. $3 \mathrm{~A}$ and $3 \mathrm{~B}$ ). The $\mathrm{m}$. LD is linked originally in the procesus spinous bone of the $1^{\text {st }}-3^{\text {rd }}$ sacrum, lumbar vertebrae, 


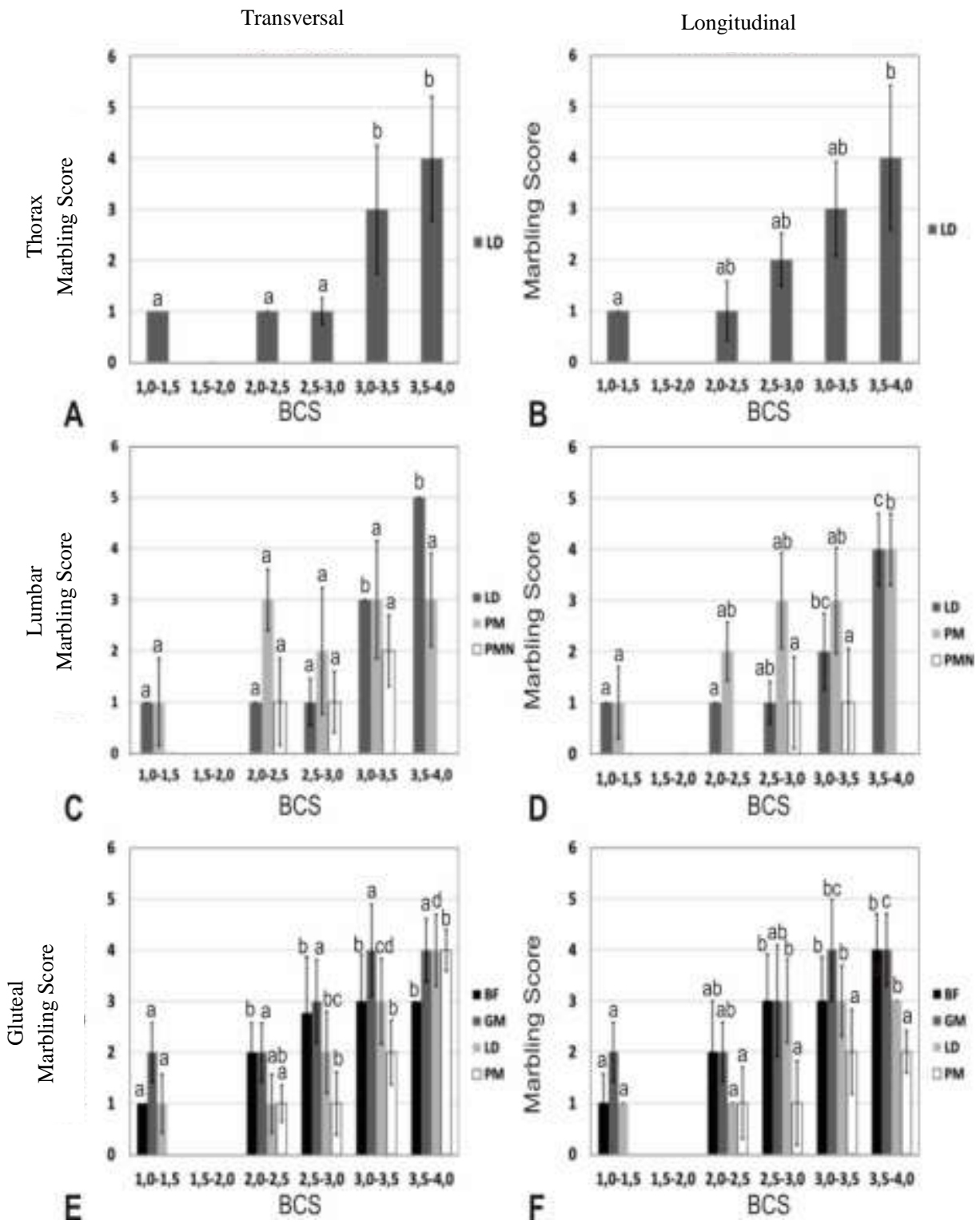

Figure 4. The marbling score is based on AUS-MEAT standard of $\mathrm{m}$. longissimus dorsi (LD), m. gluteus medius (GM), m. biceps femoris (BF), m. psoas major (PM), and m. psoas minor (PMN) in Pasundan cattle with different of BCS. A) Thorax transversal, B) Thorax longitudinal, C) Lumbar transversal, D) Lumbar longitudinal, E) Gluteal Transversal, and F) Gluteal longitudinal. Different superscript letters in the same muscle showed significant differences $(\mathrm{p}<0.05)$ between BCS in Pasundan cattle

and $13^{\text {th }}$ thoracicae vertebrae, as well as in the tuber coxae, tuber sacrale, and iliac crista from os ilium, then inserts into the lumbar vertebrae, ossa vertebrae thoracicae and fascia lata from ossa costales (Nurhidayat et al. 2016). Ultrasound imaging of tissue at the $12^{\text {th }}-13^{\text {th }}$ ribs will show a thicker $\mathrm{m}$. LD in comparison to images posterior to the $13^{\text {th }}$ rib and between $1^{\text {st }}-2^{\text {th }}$ lumbar Tait (2016).

The results in this study showed a slight difference in thickness of $\mathrm{m}$. LD, m. GM, m. BF, m. PM, and $\mathrm{m}$. PMN with three different scan locations. The $\mathrm{m}$. PM at the lumbar scan sites (Fig. 3C and 3D) showed easier imaging results when compared to the gluteal scan sites (Figure 3E and 3F). According to (Budras et al. 2003) $\mathrm{m}$. PM origin at the cranial border of the last rib $\left(12^{\text {th }}\right.$ $13^{\text {th }}$ os costales) and the transverse process of the vertebral vertebrae lumbales, meanwhile m. PM insertion in the trochanter minor os femur. M PMN was seen only in the lumbar imaging position (Figure 3C and $3 \mathrm{D}$ ). The $\mathrm{m}$. PMN origin in ossa vertebrae $12^{\text {th }}-13^{\text {th }}$ thoracic, ossa vertebrae $1^{\text {st }}$ lumbales, and crura diaphragm then $\mathrm{m}$. PMN insertion in psoas tubercle os ilium (Budras et al. 2003). Position ultrasound scans to obtain $\mathrm{m}$. GM and $\mathrm{m}$. BF images were performed on the rump section of the cow, where the coxaeal tubers and ischial tubers were oriented in the scan (Tait 2016). According to Nurhidayat et al. (2016) GM origin on the gluteal surface of the os ilium and insertion on the 


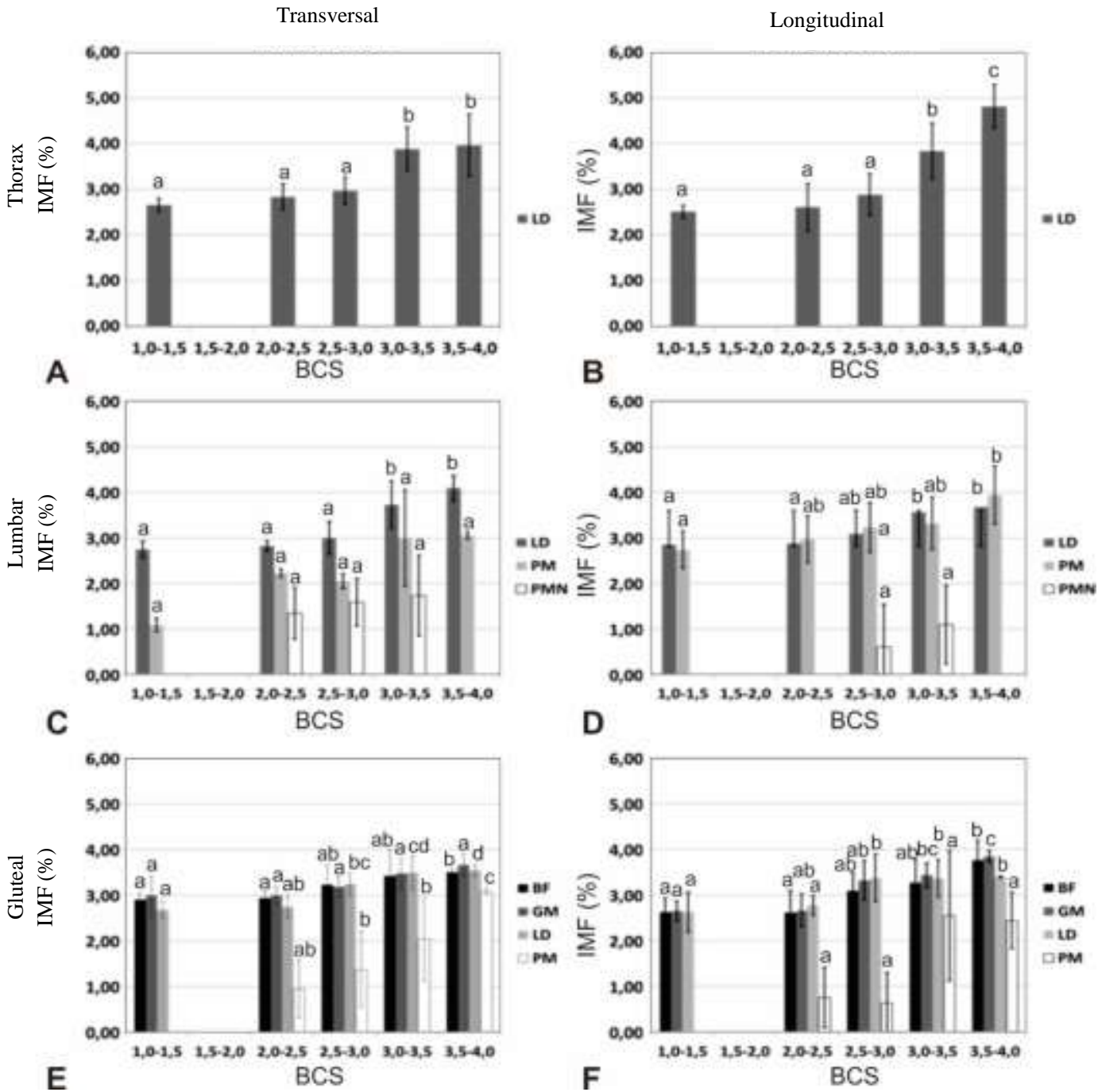

Figure 5. The value of Intramuscular Fat (IMF) based on AUS-MEAT standard $m$. longissimus dorsi (LD), m. gluteus medius (GM), $m$. biceps femoris (BF), m. psoas major (PM), and m. psoas minor (PMN) in Pasundan cattle with different of BCS. A) Thorax transversal, B) Thorax longitudinal, C) Lumbar transversal, D) Lumbar longitudinal, E) Gluteal Transversal, and F) Gluteal longitudinal. Different superscript letters in the same muscle showed significant differences $(\mathrm{p}<0.05)$ between BCS in Pasundan cattle.

greater trochanter of the femur. The $\mathrm{m}$. BF or also known as $m$ gluteobiceps that origin on the tuber ischii and median sacral crest of the sacrum then inserts into the patellar bone, tibia (fascia lata and fascia cruris), and calcaneus tendons (Budras et al. 2003).

The ultrasound imaging method can be used in determining the marbling score and the percentage of intramuscular fat as a basis for estimating the quality of meat and fat in living livestock (Gupta et al. 2013). According to Drake (2004), the quality of beef carcass is determined by the marbling score which can be measured in the ribeye between the $12^{\text {th }}-13^{\text {th }}$ ribs. Based on the results obtained, m. LD shows the highest marbling score and IMF percentage followed by $\mathrm{m}$. PM, m. GM, m. BF, and m. PMN (Figure 4 and 5). The marbling score on $\mathrm{m}$. $\mathrm{LD}$ is in the score range $1-5$ and the IMF percentage range from $2.62 \%-4.82 \%$. Pasundan cattle with BCS 3.5-4.0 had the highest marbling score and IMF percentage at $\mathrm{m}$. LD compared to low BCS (Figure 4 and 5). Based on these results, $m$. LD has been used as the standard for calculating the marbling and IMF scores by the AUS-MEAT (2020). In addition to the AUS-MEAT standard, the ribeye section $\mathrm{m}$. LD has also been used as a standard for scoring the marbling score by the Beef Marbling Standard (BMS) Japan (Gotoh et al. 2018), US Department of Agriculture (USDA) beef grades (Emerson et al. 2013), and Indonesian National Standard (SNI) 3932: 2008 concerning the quality of carcass and beef (BSN 2008).

The higher marbling and IMF scores of $\mathrm{m}$. LD than other back muscles can be caused by differences in the function and fat content of each muscle. As stated by Nuraini \& Hafid (2006), the function of each muscle will determine the distribution of fat and collagen levels in muscles. The location of $\mathrm{m}$. LD and $\mathrm{m}$. PM in the spine (spinal column) is likely to experience very rare contractions so that both muscles have lower collagen levels than $\mathrm{m}$. GM and $\mathrm{m}$. BF. This is also supported by 
Lawrie (2003) statement where collagen levels in underactive muscles such as $\mathrm{m}$. LD and $\mathrm{m}$. PM has lower collagen levels than $\mathrm{m}$ semimembranosus, $\mathrm{m}$ semitendinosus, and bicep femoris. Collagen m. PM levels are smaller than m. LD so $\mathrm{m}$. PM has a higher level of tenderness than other muscles (Carmack et al. 1995).

\section{CONCLUSION}

The Pasundan cattle body condition score influenced carcass quality on parameters such as muscle thickness, marbling score, and percentage of intramuscular fat on ultrasound images of $\mathrm{m}$. LD, $\mathrm{m}$ PM, m. GM, and m. PMN. The m. LD has the highest marbling score and percentage of intramuscular fat followed by m. PM, m. GM, m. BF, and m. PMN based on the location of ultrasound imaging on $12^{\text {th }}-13^{\text {th }}$ ribs, $4^{\text {th }}-5^{\text {th }}$ lumbar, and between the tuber coxae and tuber ischii.

\section{ACKNOWLEDGMENTS}

The researcher would like to thank the General Director of Research and Development at the Ministry of Research, Technology and Higher Education through the Higher Education Excellence Research Grant (PTUPT) through the Institute for Research and Community Services (LPPM) at the IPB University with a contract number (3/E1/KP.PTNBH/2019) and to Padjajaran University through the 2019 Lecturer Competency Grant Research (Hikom). Thank you to the Regional Technical Implementation Unit of the Center for Artificial Insemination and Artificial Insemination for Beef Cattle Development (UPTD BPPIB) at Ciamis, West Java, for providing and granting permission to use Pasundan cattle in this research. The author also thanks PT Karindo Alkesteron for providing the ultrasound device (Sonodop S-3X) used to take images in this study.

\section{REFERENCES}

AUS-MEAT Language. 2020. Handbook of Australian Beef Processing. Queensland (AU): AUS-MEAT Limited.

Bergen R, Miller S, Mandell I, Robertson W. 2005. Use of live ultrasound, weight and linear measurements to predict carcass composition of young beef bulls. Can J Anim Sci. 85:23-35.

Budras KD, Habel RE, Wunsche A, Buda S. 2003. Bovine Anatomy. Budras KD, editor. Hannover (GM): Schlütersche.

Bugiwati SRA, Harada H, Fukuhara R, Ishida T. 2000. Effect of genetic and environmental factors on meat production performance of Japanese Black bulls. Bull Fac Agric Miyazaki Univ. 47:39-49.
Carmack CF, Kastner CL, Dikeman ME, Schwenke JR, García Zepeda CM. 1995. Sensory evaluation of beefflavor-intensity, tenderness, and juiciness among major muscles. Meat Sci. 39:143-147.

Cruz-Arámbulo R, Wrigley R. 2003. Ultrasonography of the acute abdomen. Clin Tech Small Anim Pract. 18:20-31.

Dinas Peternakan Jawa Barat. 2016. Disnak Jabar Targetkan Sapi Pasundan Murni 100\% di 2018. [accessed March

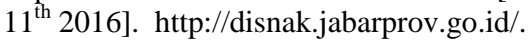

Drake DJ. 2004. Understanding and Improving Beef Cattle Carcass Quality. California (US). Agriculture and Natural Resources-University of California.

Edmonson AJ, Lean IJ, Weaver LD, Farver T, Webster G. 1989. A body condition scoring chart for Holstein dairy cows. J Dairy Sci. 72:68-78.

Emerson MR, Woerner DR, Belk KE, Tatum JD. 2013. Effectiveness of USDA instrument-based marbling measurements for categorizing beef carcasses according to differences in longissimus muscle sensory attributes1. J Anim Sci. 91:1024-1034.

Gotoh T, Nishimura T, Kuchida K, Mannen H. 2018. The Japanese Wagyu beef industry: current situation and future prospects - A review. Asian-Australasian J Anim Sci. 31:933-950.

Gupta S, Kumar A, Kumar S, Bhat ZF, Hakeem HR, Abrol APS. 2013. Recent trends in carcass evaluation techniques-a review. J Meat Sci Technol. 1:50-55.

Indrijani, Johar A, Dudi, Wendry S, Romi Z, Hilmia. 2012. Kajian Identifikasi Sapi Lokal Jawa Barat dalam Mendukung Swasembada daging sapi. Laporan Penelitian. Bandung (Indones): Dinas Peternakan Provinsi Jawa Barat.

Jakaria J, Khasanah H, Priyanto R, Baihaqi M, Ulum MF. 2017. Prediction of meat quality in Bali cattle using ultrasound imaging. J Indones Trop Anim Agric. 42:59.

Juandhi M, Kurnia D, Anwar P. 2019. Pendugaan body condition scoring (BCS) terhadap bobot badan, bobot karkas dan persentase karkas Sapi Brahman Cross (BX) di RPH kota pekanbaru. J Anim Cent. 1:37-45.

Kementerian Pertanian. 2014. Keputusan Menteri Pertanian Nomor 1051/Kpts/SR.120/10/2014 Tentang Penetapan Rumpun Sapi Pasundan. Jakarta (Indones): Kementerian Pertanian Republik Indonesia

Lambe NR, Haresign W, Macfarlane J, Richardson RI, Matika O, Bünger L. 2010. The effect of conditioning period on loin muscle tenderness in crossbred lambs with or without the Texel muscling QTL (TM-QTL). Meat Sci. 85:715-720.

Lawrie R. 2003. Ilmu Daging. Jakarta (Indones): Universitas Indonesia Press.

M'hamdi N, Frouja S, Bouallegue M, Aloulou R, Kaur S, Brar, Hamouda M. 2012. Milk Production - An Up-toDate Overview of Animal Nutrition, Management and Health. Chaiyabutr N, editor. London (UK): InTech.

Nasional BS. 2008. Mutu Karkas dan Daging Sapi. Jakarta (Indones): Badan Standardisasi Nasional. 
Nold RA, Unruh JA, Spaeth CW, Minton JE. 1992. Effect of zeranol implants in ram and wether lambs on performance traits, carcass characteristics, and subprimal cut yields and distribution1. J Anim Sci. 70:1699-1707.

Noviana D, Aliambar S, Ulum M, Siswandi R, Gunanti, Soehartono R, Soesatyoratih R, Zaenab S. 2018. Diagnosis Ultrasonografi pada Hewan Kecil. Bogor (Indones): IPB Press.

Nuraini, Hafid H. 2006. Karakteristik kualitas daging sapi peranakan ongole yang berasal dari otot longissimus dorsi dan gastrocnemius. J Ilm Ilmu-ilmu Peternak. 9:250-257.

Nurhidayat, Nisa C, Agungpriyono S, Setijanto H, Novelina S, Supratikno, Cahyadi D. 2016. Osteologi dan Miologi Veteriner. Bogor (Indones): IPB Press.

Otto KL, Ferguson JD, Fox DG, Sniffen CJ. 1991. Relationship Between Body Condition Score and Composition of Ninth to Eleventh Rib Tissue in Holstein Dairy Cows. J Dairy Sci. 74:852-859.

Roche JR, Friggens NC, Kay JK, Fisher MW, Stafford KJ, Berry DP. 2009. Invited review: Body condition score and its association with dairy cow productivity, health, and welfare. J Dairy Sci. 92:5769-5801.

Silva S da L e, Tarouco JU, Ferraz JBS, Gomes R da C, Leme PR, Navajas EA. 2012. Prediction of retail beef yield, trim fat and proportion of high-valued cuts in Nellore cattle using ultrasound live measurements. Rev Bras Zootec. 41:2025-2031.

Stouffer JR. 2004. History of Ultrasound in Animal Science. J Ultrasound Med. 23:577-584.

Syaifudin A. 2013. Profil Body Condition Score (BCS) Sapi Perah di Wilayah Koperasi Peternakan Sapi Bandung Utara (KPSBU) Lembang (Studi Kasus) [Thesis]. [Bogor (Indones)]: IPB University.

Tait RG. 2016. Ultrasound use for body composition and carcass quality assessment in cattle and lambs. Vet Clin North Am Food Anim Pract. 32:207-218.

Ulum MF, Suprapto E, Jakaria. 2014. Citra ultrasonografi otot punggung (longisimus dorsi) pada sapi bali. Prosiding KIVNAS PDHI XIII (Konverensi Ilmiah Veteriner Nasional ke-13) Perhimpunan Dokter Hewan Indonesia, Palembang, 23-26 November 2014. Palembang (ID): p. 368-369. 